\title{
WSPÓLPRACA MIĘDZYPARLAMENTARNA RADY NORDYCKIEJ Z PERSPEKTYWY KONSTRUKTYWIZMU
}

Rada Nordycka jest organem współpracy międzyparlamentarnej między krajami nordyckimi. Obejmuje Danię, Finlandię, Islandię, Norwegię, Szwecję, Wyspy Owcze, Grenlandię i Wyspy Alandzkie. Współpraca nordycka ma głębokie korzenie w polityce, ekonomii i kulturze. Koncentruje się na obszarach, w których podejście nordyckie generuje wartość dodaną dla krajów i narodów regionu oddziałuje na społeczność wielu państw na świecie. Celem artykułu jest analiza współpracy międzyparlamentarnej między państwami nordyckimi. Podejmuje on zagadnienie wpływu Rady Nordyckiej na społeczeństwo tego regionu. Autor wykorzystał metodę porównawczą, aby odpowiedzieć na pytanie, w jaki sposób propozycje Rady Nordyckiej wpływają na społeczeństwo państw nordyckich oraz pozostałych regionów na świecie. W artykule zastosowano podejście konstruktywistyczne, które daje możliwość znalezienia zależności między ideami oraz normami a tożsamością społeczną.

Słowa kluczowe: Rada Nordycka, region nordycki, stosunki międzynarodowe

\section{THE NORDIC COUNCIL AS INTER-PARLIAMENTARY BODY FOR COOPERATION IN THE NORDIC COUNTRIES. A CONSTRUCTIVIST APPROACH}

The Nordic Council is the official body for formal inter-parliamentary co-operation among the Nordic countries, i.e., Denmark, Finland, Iceland, Norway, Sweden, the Faroe Islands, Greenland and Åland. It is deeply rooted in politics, economics and culture. It focuses on areas where a Nordic approach generates added value for the countries and nations of the region and affects the community of multiple countries around the world. The aim of the article is to analyze inter-parliamentary cooperation between Nordic countries and the Nordic Council influence's on Nordic society. The author uses comparative methods to answer the question of how the Nordic Council proposals influence the Nordic societies and the rest of the world. In the article a constructivist approach is applied, which allows finding dependences between ideas or norms and the social identity in the Nordic region.

Key words: Nordic Council, Nordic Region, International Relations

* Dr hab. Magdalena Tomala, Uniwersytet Jana Kochanowskiego w Kielcach, magdalena2828@gmail.com, https://orcid.org/0000-0002-1654-3590

I. WSTĘP

$\mathrm{W}$ literaturze przedmiotu stosunków międzynarodowych panuje zgoda, że współpraca państw nordyckich opiera się na wspólnych wartościach, więziach oraz historii ${ }^{1}$. Można do nich zaliczyć m.in. poszanowanie zasad demokracji,

1 K. Musiał, Roots of the Scandinavian Model. Images of Progress in the Era of Modernisation, Berlin 2000, s. 9, 42. J. Nowiak, Wspótpraca nordycka. Wzór dobrej polityki, Poznań 2001; K. Dośpiał-Borysiak, Northern Europe. New Political, Economic and Social Trends, „International Studies. Interdisciplinary Political and Cultural Journal" 2017, t. 20, nr 1, s. 7. 
w tym praw jednostki, silne społeczeństwo obywatelskie, ochronę środowiska, kulturę czy opiekę nad słabszymi². W tym kontekście warto przyjrzeć się jednej z wielu instytucji współpracy państw nordyckich, tj. Radzie Nordyckiej. Podjęła ona próbę współpracy międzyparlamentarnej w rozwiązywaniu wspólnych problemów tego regionu. Jej unikalność wynika z charakteru tej organizacji. Członkami Rady są przedstawiciele parlamentów państw nordyckich: Szwecji, Danii, Norwegii, Finlandii, Islandii oraz terytoriów zależnych, tj. Wysp Alandzkich, Wysp Owczych oraz Grenlandii.

W wielu polskich pracach został podjęty wątek charakteru, struktury i działania Rady Nordyckiej. W literaturze przedmiotu można znaleźć studia i rozprawy z tego zakresu takich autorów jak: Joanna Grzela ${ }^{3}$, Bernard Piotrowski ${ }^{4}$, Michał Jan Filipek ${ }^{5}$, Ryszard Zięba ${ }^{6}$, Zbigniew Doliwa-Klepacki, Rafał Lawniczak ${ }^{7}$ in. Brakuje jednak opracowania, w którym by omówiono, jaka jest skuteczność i oddziaływanie Rady Nordyckiej w społeczeństwach państw nordyckich.

Celem artykułu jest analiza funkcjonowania Rady Nordyckiej w świetle konstruktywizmu, a w szczególności porównanie relacji między normami, które wytycza Rada Nordycka, a tożsamością państw nordyckich. Według konstruktywizmu kultura światowa zajmuje się dyfuzją norm kulturowych między państwami. Zdaniem przedstawicieli szkoły stanfordzkiej wpływ na stosunki międzynarodowe mają światowe modele organizacji społeczności ludzkiej, które są promowane przez organizacje międzynarodowe, społeczność akademicką oraz ekspertów ${ }^{8}$. Odnosząc się do konstruktywizmu, można postawić pytanie, jaki rodzaj tożsamości mają państwa nordyckie. Jak podkreślił Ted Hopf w pracy The Promise of Constructivism in International Relations Theory, państwa w systemie międzynarodowym mogą mieć tożsamość współzawodniczącą i egoistyczną lub współpracującą i nastawioną na osiągnięcie dobra wspólnego9. Jaka jest gotowość tych państw do współpracy oraz w jakim stopniu państwa przestrzegają bądź nie norm, wytyczonych przez Radę Nordycką? Można przypuszczać, że sukces członków Rady Nordyckiej jest wynikiem zmiany tożsamości, funkcji i statusu w obszarach narzuconych przez Radę Nordycką. Udaje im się reprodukować narzucone normy w codziennej praktyce społecznej, dzięki czemu osiągają przewagę nad innymi podmiotami stosunków międzynarodowych w wytyczonych, priorytetowych dla siebie dziedzinach.

${ }^{2}$ A. Zygierewicz, Wspólpraca państw nordyckich, Kancelaria Sejmu. Biuro Studiów i Ekspertyz, 2005, nr 1115, s. 1.

3 J. Grzela, Płaszczyzny i kierunki współpracy nordyckiej, Kielce 2014, s. 29 i n.

${ }^{4}$ B. Piotrowski, Integracja Skandynawii. Od Rady Nordyckiej do wspólnoty europejskiej, Poznań 2005.

${ }_{5}^{5}$ M.J. Filipek, Struktura organizacyjna oraz główne kierunki działalności Nordyckiej Rady Ministrów, „Zeszyty Prawnicze UKSW” 2009, t. 9, nr 2.

${ }^{6} \mathrm{R}$. Zięba, Rola ugrupowań subregionalnych $w$ nowym systemie bezpieczeństwa europejskiego, „Studia Europejskie” 2000, nr 1, s. 27-51.

7 Z. Doliwa-Klepacki, R. Ławniczak, Rada Nordycka a wspótpraca i integracja państw skandynawskich, Warszawa 1978.

${ }^{8}$ G.M. Thomas, J. Meyer, F.O. Ramirez, Institutional Structure. Constituting State, Society and Individual, red. J. Boli, Newbury Park 1987, s. 198.

9 T. Hopf, The Promise of Constructivism in International Relations Theory, „International Security” 1998, t. 23, nr 1, s. 175. 
Ponadto sami tworzą normy, które udaje im się przenieść na poziom międzynarodowy. W pracy zastosowano metodę porównawczą, która pozwala rozstrzygnąć, jakie jest podejście społeczeństw tego regionu do proponowanych norm i reguł wytyczanych przez Radę Nordycką. Artykuł składa się z trzech części. W pierwszej zostanie przybliżone podejście konstruktywizmu do badania organizacji międzynarodowych oraz implementacji norm w społeczności międzynarodowej. W drugiej części zostanie omówiony proces kształtowania się norm w tej organizacji. Zostanie zwrócona uwaga na korzenie współpracy nordyckiej, jej rozwój w kontekście przyjmowanych norm i zasad działania. Z kolei w ostatniej części zostaną porównane normy wyznaczane przez Radę Nordycką do praktyki działania państw nordyckich.

\section{ZALOŻENIA KONSTRUKTYWIZMU W BADANIU ORGANIZACJI MIĘDZYNARODOWYCH}

Konstruktywizm jako jedna $\mathrm{z}$ teorii w nauce o stosunkach międzynarodowych pojawiła się dość późno, bo dopiero w latach dziewięćdziesiątych XX w. Teoria powstała w opozycji do paradygmatu racjonalistycznego, który był syntezą neorealizmu i neoliberalizmu. Jej podstawy skonstruował Johan Ruggie, w pracy Continuity and Transformation in the World Polity. Towards a Neorealist Synthesis. Ruggie odniósł się w niej krytycznie do teorii polityki międzynarodowej Waltza z 1983 r., wskazując, że państwa zorganizowane są według różnych zasad ${ }^{10}$. Kolejnym badaczem, który wytyczył drogę konstruktywizmowi był Richard Ashley, który w 1984 r. krytycznie odniósł się do reali$\mathrm{zmu}^{11}$. Z kolei w $1987 \mathrm{r}$. Alekxander Wendt do dyskursu na temat stosunków międzynarodowych wprowadził termin agent-struktura ${ }^{12}$. Wskazane prace podkreślały przede wszystkim wpływ idei na politykę światową.

Wzrost zainteresowania tą teorią wynikał ze słabości prognostycznej teorii tradycyjnych $^{13}$. Konstruktywiści krytykowali realistów za reifikowanie takich pojęć jak państwo, interes czy potęga, gdy dla realistów były to elementy obiektywne i niezależne od ludzkiej świadomości. Istotą konstruktywizmu jest teza, że ludzie podlegają socjalizacji przez normy obowiązujące w społeczeństwie. Proces ten przyczynia się do przyswajania kultury i uczenia się ról społecznych. Podobne zjawisko możemy zaobserwować na płaszczyźnie międzynarodowej. Jak wskazał Torbjorn L. Knutsen, państwa podlegają socjalizacji poprzez normy obowiązujące w danej społeczności międzynarodowej. Są one słabsze niż w społecznościach wewnątrz państwa, stąd mają większą swobodę działania w strukturze systemu międzynarodowego. Zdaniem Nicholasa Onufa, przedstawiciela konstruktywizmu, relacje między państwem a systemem międzynarodowym

10 J.G. Ruggie, Continuity and Transformation in the World Polity. Towards a Neorealist Synthesis, „World Politics” 1983, t. 2, nr 35, s. 261-285.

${ }^{11}$ R.K. Ashley, The Poverty of Neo-realism, „International Organization” 1984, nr 38, s. 225-286.

12 A. Wendt, The Agent Structure Problem in International Relations Theory, „International Organization" 1987 , t. 41, nr 3, s. 335-370.

${ }^{13}$ S. Guzzini, A Reconstruction of Constructivism in International Relations, „European Journal of International Relations" 2000, t. 6, nr 2, s. 154-155. 
mają charakter dwukierunkowy. Ludzie tworzą społeczeństwo i odwrotnie, a zasady pośredniczą $\mathrm{w}$ procesie wzajemnego tworzenia się. $\mathrm{W}$ tym sensie zasady spełniają rolę celów, wytycznych wskazujących, co należy robić w danej sytuacji. Określają, kto jest w społeczności agentem, czyli aktywnym uczestnikiem ${ }^{14}$. Jak podkreśla Onuf, w stosunkach międzynarodowych państwom charakter nadaje struktura systemu międzynarodowego. Działania odnoszące się do zasad nazywamy praktykami. Należy jednak pamiętać, że działania mogą dotyczyć zarówno przestrzegania zasad, jak również ich łamania, obchodzenia, zmieniania lub eliminowania. Obserwacja praktyk stosowanych przez państwa może pomóc w odkryciu zasad rządzących stosunkami międzynarodowymi oraz wskazać tożsamość państw w tym systemie.

Martha Finnemore dzieli strukturę społeczności międzynarodowej na strukturę głęboką i powierzchniową. Według niej strukturę głęboką tworzą normy, które socjalizują państwa, sprawiając, że ich zachowanie staje się zgodne z zasadami i wzorami wytyczanymi przez organizacje międzynarodowe. Normy z kolei możemy podzielić na biurokratyczne, wynikające ze sposobu wykonywania władzy, normy rynku i normy równości. Natomiast strukturę powierzchniową tworzą organizacje międzynarodowe i aktorzy pozarządowi, którzy rozpowszechniają normy, ucząc w ten sposób państwa właściwego zachowania.

Istotnego znaczenia nabiera $\mathrm{w}$ analizie stosunków międzynarodowych kryterium przestrzegania wyznaczanych norm, o czym napisał William Rees ${ }^{15} \mathrm{w}$ pracy The Theory of Sovereignty Restated w 1950 r. Wyodrębnił on trzy rodzaje władzy:

— władzę przymusu, gdy reguły przestrzegane są z obawy przed siłą,

— władzę zwyczaju, gdy reguły przestrzegane są w obawie przed dezaprobatą społeczną,

— władzę moralności, gdy reguły są zgodne z przekonaniami i świadomością aktorów.

Odwołując się do niego, Wendt wskazał, że w stosunkach międzynarodowych różny jest stopień internalizacji norm międzynarodowych. Najniższy poziom prezentują państwa, które przestrzegają norm, ponieważ są do tego przymuszane. Następny poziom dotyczy państw, które uznają normy, ponieważ leży to w ich interesie. Najwyższy poziom osiągają te podmioty, które uznają normy za słuszne. Jak podkreśla Wendt, wskazane trzy poziomy są wynikiem oddziaływania ${ }^{16}$ :

— kultury hobbesowskiej, tj. kultury wrogości, która charakteryzuje się brakiem ograniczeń stosowania siły;

— kultury locke'owskiej, tj. kultury rywalizacji, w której siła używana jest do realizacji swoich interesów, choć nie do zniszczenia przeciwnika;

— kultury kantowskiej, tj. kultury przyjaźni, w której nie stosuje się siły w relacjach między państwami.

${ }^{14}$ N. Onuf, A Constrctivism Manifesto, [w:] Constituting International Political Economy, red. K. Burch, R.A. Denemark, London 1997, s. 7-10.

${ }_{15}$ W. Rees, The Theory of Sovereignty Restated, „Mind” 1950, t. 59, nr 236, s. 508-509.

${ }^{16}$ A. Wendt, Social Theory of International Politics, Cambridge 1999, s. 286-290. 
Podsumowując, można wyciągnąć wniosek, że tylko w kulturze kantowskiej, która odwołuje się do moralności, kulturze przyjaźni i współpracy możliwe jest uzyskanie przez współpracujące ze sobą państwa tożsamości nastawionej na osiągnięcie dobra wspólnego. Pozostałe kultury decydują się na rywalizację lub konflikt, próbując osiągnąć własne korzyści i zrealizować własne interesy. Warto jednak pamiętać, że w literaturze przedmiotu brakuje opracowań wskazujących na wyższość jednej z wymienionych kultur — to od społeczeństwa oraz rządzących zależy, jaką kulturę będą stosować.

\section{ROZWÓJ WSPÓLPRACY PARLAMENTARNEJ W RAMACH RADY NORDYCKIEJ}

Idea powstania Rady Nordyckiej narodziła się w okresie napięć politycznych między Wschodem a Zachodem ${ }^{17}$. W sytuacji konfliktu i rywalizacji mocarstw światowych Nordycy zauważyli potrzebę stworzenia szerszego forum współpracy w obszarze gospodarczym, politycznym i kulturalnym ${ }^{18}$. W 1949 r., podczas posiedzenia Rady Europy w Strasburgu, pracując w oddzielnych narodowych komitetach parlamentarnych, dochodzili do podobnych wniosków oraz ustaleń ${ }^{19}$. Już wtedy państwa nordyckie postępowały zgodnie z logiką poprawności, zasadami, które wszystkie te podmioty uznawały za słuszne. Według konstruktywizmu taki stan można określić jako izomorfizm. Zdaniem Johna W. Meyera (i in.), przejawia się on w podejmowaniu przez państwa podobnych decyzji, występowaniem podobieństw w organizacji wewnętrznej państw, rozwiązań instytucjonalnych, prawa wewnętrznego, systemu szkolnictwa, pomocy społecznej, pracy i imigracji ${ }^{20}$.

Występujący między państwami nordyckimi izomorfizm przyczynił się do tego, że delegaci skandynawscy wyszli z propozycją utworzenia nordyckiego organu parlamentarnego, aby skutecznie i szeroko przedyskutować sprawy tzw. wspólnego zainteresowania. Jak stwierdził Niklas Luhmann, podstawą komunikacji między elementami systemu jest siatka znaczeń określonych przez czynniki kulturowe. Znaczenia przypisywane są poszczególnym symbolom i są zrozumiałe jedynie w ramach danej siatki ${ }^{21}$. Ówcześnie można było zaobserwować proces tworzenia siatki nordyckich

${ }^{17}$ H.D. Karich, Der Nordische Rat. Institution skandinavischer Gemeinsamkeit im Umfeld divergierender sicherheits- und wirtschaftlicher Interessen der Mitgliedstaaten, Diss, Kiel 1999, s. 75, cyt. za: B. Piotrowicz, Integracja Skandynawii. Od Rady Nordyckiej do wspólnoty europejskiej, Poznań 2006, s. 46.

${ }^{18}$ Confer Rhetorics of Nordic Democracy, red. J. Kurunmäki, J. Strang, Helsinki 2010; M. Hilson, The Nordic Model: Scandinavia since 1945, London: 2008; The Cold War and the Nordic Countries: Historiographies at the Crossroads, red. T.B. Olesen, Odense 2004; J. Strang, Introduction: The Nordic Model of Transnational Cooperation, [w:] Nordic Cooperation: A European Region in Transition, red. J. Strang, London 2016, s. 1-26.

19 F. Wendt, Cooperation in the Nordic Countries. Achievements and Obstacles, Stockholm 1981, s. 34.

20 J.W. Meyer, J. Boli, G.M. Thomas, F.O. Ramirez, World Society and the Nation State, „American Journal of Sociology" 1997, t. 103, nr 1, s. 144-181.

21 N. Luhmann, Essays on Self-Reference, New York 1990. Vide M. Albert, Observing World Politics. Luhmann's Systems Theory of Society and International Relations, „Millenium” 1999, t. 28, nr 2, s. 239-265. 
znaczeń. Urzeczywistnieniem tych procesów było powołanie Nordyckiej Unii Międzyparlamentarnej, która w 1951 r. utworzyła Skandynawski Komitet Międzyparlamentarny (Skandinavisk Interparlamentarisk Komite), który koncentrował swoje działania na przygotowaniu wielu istotnych propozycji, np. zniesienie paszportów upraszczające przygraniczną procedurę celną czy obniżające taryfy pocztowo-telekomunikacyjne. Należy zauważyć, że już pierwsze próby rozwiązywania wspólnych problemów przyniosły oczekiwane rezultaty dla państw nordyckich. Przyspieszyło to proces integracji regionu nordyckiego, przyczyniło się również do pogłębienia izomorfizmu między podmiotami nordyckimi oraz wzmocniło rozwój gospodarczy tego regionu.

Dnia 13 sierpnia 1951 r. na posiedzeniu Nordyckiej Unii Międzyparlamentarnej duński polityk Hans Hedtof wystąpił z exposé w sprawie współpracy nordyckiego parlamentu. Podkreślał, że zachowanie pokoju i wolności wymaga współpracy i współdziałania całego regionu w takich kwestiach jak sprawy gospodarcze, prawne i polityczne ${ }^{22}$. W tym procesie niezwykle pomocne było powołanie Nordisk Riksdag, czyli parlamentu nordyckiego, którego funkcje nie tyle wykonawcze, co raczej doradcze miały pomóc w kreowaniu kierunków współpracy.

Czy możemy zatem mówić o Radzie Nordyckiej jako o organizacji, która w sposób rzetelny poszukiwała prawdy i porozumienia, dążąc do wytworzenia wspólnej rzeczywistości oraz zinstytucjonalizowania poszczególnych obszarów tematycznych? Jak podkreślił Jurgen Habermas, ,aby prawdziwa wymiana argumentacji mogła nastąpić, aktorzy winni posiadać umiejętność empatii, dzielić wspólną rzeczywistość (język, kulturę, historię) oraz wzajemnie uznawać swoją równość w wyrażaniu stanowiska w dys-

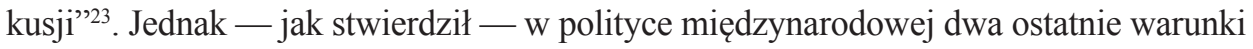
nie są możliwe do spełnienia, gdyż stosunki międzynarodowe są anarchiczne, a relacje między państwami determinuje układ sił ${ }^{24}$. Tym samym ich równość jest pozorna, gdyż państwa nie dzielą wspólnego języka, kultury i historii ani wspólnej wizji świata, lecz dążą do narzucenia własnej wizji czy interpretacji.

Analizując historię powstania Rady Nordyckiej, należy zwrócić uwagę, że nie tylko parlamentarzyści dostrzegali potrzebę kooperacji tych małych państw położonych w północnej części Europy. Również przedstawiciele rządów zauważali korzyści stworzenia „nordyckiego forum współpracy”. W tej kwestii wypowiedział się zarówno premier Norwegii Einar Gerhardsen, który zaapelował o szersza debatę o współpracy, jak też szwedzki minister spraw zagranicznych Östen Unden, który nakreślił ideę i zasady działania Rady Nordyckiej oraz podkreślał m.in., aby nie rozłączać tak rozumianej centralnej instytucji parlamentarnej od działalności poszczególnych rządów ${ }^{25}$. Całość

${ }^{22}$ H. Hedtoft, Nordisk Råd, „Nordisk Administrativt Tidsskrift” 1953, s. 266, za B. Piotrowski, op. cit.

${ }^{23}$ J. Habermas, Teoria działania komunikacyjnego, thum. A.M. Kaniowski, t. 1, Warszawa 1999, t. 2 , Warszawa 2002; J. Czaputowicz, Teorie stosunków międzynarodowych. Krytyka i systematyzacja, Warszawa 2007, s. 319.

${ }^{24}$ Ibidem.

${ }_{25}$ B. Piotrowski, op. cit., s. 42-43. 
przedsięwzięcia przygotował Nils Herlitz, szwedzki prawnik, który stworzył statut tej organizacji. Za kluczowe przyjął on odwołanie się do skandynawskiej tradycji struktur prawnoadministracyjnych regionu oraz do tradycji nordyckiej samorządności $\mathrm{i}^{26}$. Odwoływał się do wartości i zasad, które Habermas określał jako typowe dla państwa, a nie organizacji międzynarodowej. Dokument został przedstawiony na posiedzeniu komitetu 24 października 1951 r., a zaakceptowany w grudniu 1951 r. w Sztokholmie. W tym sensie Rada Nordycka może być przykładem instytucji, co do której trudno zgodzić się z założeniami Habermasa. Świadczy to również o wyjątkowym znaczeniu tej organizacji w stosunkach międzynarodowych, gdzie występuje model kultury przyjaźni, i w której nie stosuje się siły w relacjach między państwami. W działaniu Rady Nordyckiej ważne były nie tyle zobowiązania prawne, ile wspólnota zaufania i doświadczenia ${ }^{27}$. Rada składała się z 69 przedstawicieli (obecnie 87) wybieranych i wyznaczanych przez parlamenty poszczególnych państw nordyckich. W pracach Rady uczestniczyli reprezentanci rządów. Choć prawo zabierania głosu mieli wszyscy, jednak głosować mogli jedynie parlamentarzyści ${ }^{28}$.

W następnych latach wzrosła liczba specjalistycznych komitetów działających w sferze ekonomii, prawa, kultury i życia społecznego. Zajmowały się takimi sprawami jak: rynek pracy, polityka energetyczna, prawo karne, sprawy komunikacyjne oraz środki masowego przekazu. W 1957 r. dokonano zmian w statucie Rady, mocniej podkreślając wagę i znaczenie wspólnoty działania Skandynawów w rozwiązywaniu problemów bieżących, umocniono pozycję Prezydium Rady oraz zwiększono liczbę ministrów uczestniczących w jej pracach.

Na początku lat sześćdziesiątych XX w. dostrzeżono potrzebę rozszerzenia zakresu działania Rady o sprawy międzynarodowe. Działania te zaowocowały podpisaniem 23 marca 1962 r. przez rządy Danii, Islandii, Finlandii, Norwegii, Szwecji tzw. umowy z Helsinek, zgodnie z którą wydzielono pięć zasadniczych dziedzin współpracy nordyckiej ${ }^{29}$ :

— konsultacje dotyczące spraw wspólnego zainteresowania Skandynawów w międzynarodowych organizacjach i konferencjach;

- pomoc dyplomatyczna poza granicami Skandynawii obywatelom z tego regionu;

— koordynacja nordyckiej pomocy (np. ekonomicznej, prawnej, kulturalno-oświatowej) dla krajów rozwijających się;

— współpraca w dziedzinie statystyki;

— wspólne wysiłki na rzecz rozszerzania wiedzy o krajach nordyckich poza granicami tego regionu.

${ }^{26}$ N. Herlitz, Nordiska rådets tillkmst. Minnen från 1951-1953, Stockholm 1962.

27 Vide G. Petren, The Nordic Council. A Unique Factor in International Law, „Nordisk Tidskrift for International Ret og Jus Gentium" 1959, t. 29, nr 4, s. 346-362.

${ }^{28}$ Nordic Council, Forretningsorden for Nordisk Råd, <https://www.norden.org/en/information/ forretningsorden-nordisk-rad>, dostęp 5 IV 2019.

29 B. Piotrowski, op. cit., s. 48. 
Umowa z Helsinek nazywana jest kamieniem węgielnym nordyckiej współpracy. Trzeba podkreślić, że w 40 artykułach Nordycy zawarli listę konkretnych form współpracy regionalnej w takich sprawach jak: kultura, prawo, polityka społeczna, ekonomia, transport i komunikacja ${ }^{30}$. Co ważne, propozycje wysuwane przez Radę Nordycką nie pozostają w próżni. Adresatem zaleceń i opinii Rady Nordyckiej jest Nordycka Rada Ministrów, która została powołana w 1971 r. Jest ona forum współpracy na szczeblu rządowym. Te dwa podmioty ściśle współpracują ze sobą, co sprawia, że pomysły i projekty wysuwane przez Radę Nordycką są wcielane w życie ${ }^{31}$.

Wyjątkowym zjawiskiem, o którym warto wspomnieć, jest proces zmian strukturalnych, jaki następował w kolejnych latach. W początkowym okresie członkami Rady Nordyckiej były jedynie Szwecja, Dania, Norwegia oraz Islandia. Mimo że w swych założeniach miała być to organizacja opierająca się na współpracy wszystkich państw nordyckich, to początkowo Finlandia nie uczestniczyła w sesjach Rady z powodu zagrożenia ze strony rosyjskiej. Dopiero w październiku 1955 r. parlament Finlandii po konsultacjach z ZSRR wyraził zgodę na udział w obradach. Kiedy w styczniu 1956 r. delegaci z Finlandii byli obecni podczas sesji Rady, premier Szwecji podkreślił, że bez Finlandii w Radzie Nordyckiej pozostawało jedno tzw. puste krzesło, a dzięki jej przyłączeniu się nordycki krąg stał się kompletny. Inne wypowiedzi polityków nordyckich świadczą o tym, że ich własne korzyści i interesy nie były ważniejsze niż wspólny interes regionalny. Wytyczane normy i obszary działania potwierdzają, że Nordykom nie zależało na rywalizacji między sobą, ale rozumieli oni znaczenie synergii wynikającej ze współpracy. Dzięki takiemu podejściu możliwe było poszerzenie Rady na obszary tzw. Skandynawii atlantyckiej (Vestnorden). Do współpracujących państw dołączyły w kolejnych latach na prawach oddzielnego członka Wyspy Owcze, Wyspy Alandzkie oraz Grenlandia, powiększając liczbę członków Rady do 87. Miało to znaczenie symboliczne dla całego regionu Norden, gdyż było to nie tylko zaproszenie do współpracy, ale również dawało im równe prawa oraz uznanie ich prawa do samostanowienia ${ }^{32}$.

Można zatem przyjąć, że w założeniu Rada Nordycka miała na celu stworzenie organizacji współpracującej i nastawionej na osiągnięcie wspólnego dobra. Choć teoria zaprezentowana przez Habermasa dezawuuje taką możliwość, Radzie Nordyckiej udało się osiągnąc zamierzony cel. Natomiast należy pamiętać, że Rada Nordycka była jedynie organem konsultatywnym, a jej rekomendacje nie były wiążące dla poszczególnych rządów. Ponadto nie rozporządzała ona funkcjami prawodawczymi, a jej kompetencje były dość ogólne. Uprawnienia, jakie otrzymała Rada Nordycka, były zdecydowanie słabsze niż w społecznościach wewnątrz państw nordyckich, stąd Rada miała większą swobodę działania w strukturze systemu międzynarodowego. Jej ogromnym

${ }^{30}$ C. Wiklund, 1962 års Helsingavtal, [w:] Norden i sicksack. Tre spårbyten inom nordiskt samarbete, red. B. Sundelius, C. Wiklund, Stockholm 2000, s. 92-103.

31 Vide M.J. Filipek, Struktura organizacyjna oraz główne kierunki działalności Nordyckiej Rady Ministrów, „Zeszyty Prawnicze UKSW” 2009, nr 2, s. 109-118.

32 The Nordic Council, <https://www.norden.org/en/nordic-council>, dostęp 9 IV 2019. 
walorem było to, że nie była żadnym organem ponadnarodowym, natomiast szanowała wewnętrzne prawo państw nordyckich. O jej sile decydował nie przymus, ale chęci do współpracy oraz konsensu.

\section{PRAKTYKA FUNKCJONOWANIA RADY NORDYCKIEJ W ŚWIETLE KONSTRUKTYWIZMU}

Odwołując się do struktury powierzchniowej i głębokiej, należy zauważyć, że Rada Nordycka pełni obie te funkcje. Socjalizuje państwa nordyckie, sprawiając, że konkurencyjność, innowacyjność, zrównoważony rozwój, demokracja, ochrona środowiska, edukacja są kojarzone z wartościami nordyckimi. Należy również podkreślić, że równocześnie tworzy ona strukturę powierzchniową, rozpowszechniając nordyckie wartości i normy na forum innych organizacji międzynarodowych oraz w innych państwach. Tym samym idee oraz zasady są wdrażane i realizowane w praktyce. Wartości proponowane w ramach Rady Nordyckiej wpływają na tożsamość społeczeństw państw nordyckich, jak też są rozpowszechniane wśród społeczności innych państw na świecie.

\section{Struktura glęboka}

Należy zwrócić uwagę na pierwszy aspekt, tj. strukturę głęboką. Zdaniem M. Finnemore, strukturę głęboką tworzą normy, które socjalizują państwa, sprawiając, że ich zachowanie staje się zgodne z zasadami i wzorami wytyczanymi przez organizacje międzynarodowe. W tym kontekście należy odnieść się do tożsamości państw oraz poddać analizie sposoby wdrażania wytycznych przez Radę Nordycką norm i zasad ${ }^{33}$.

Początkowo w ramach Rady Nordyckiej działały cztery komitety: do spraw kultury, kwestii ekonomiczno-komunikacyjnych, spraw społecznych oraz prawnych. Obecnie krąg zainteresowań Rady Nordyckiej jest znacznie szerszy i obejmuje wiele dziedzin, w których współpraca ma na celu przyczynić się do integracji całego regionu nordyckiego i bałtyckiego. Możemy wyróżnić takie obszary jak: cyfryzacja, niepełnosprawność, środowisko i klimat, zrównoważony rozwój, dzieci oraz młodzież, energia, sztuka i kultura, edukacja i badania, równouprawnienie, język, wolność i swoboda poruszania $\operatorname{się}^{34}$.

Projekt dotyczący cyfryzacji ma kilka celów: stworzenie jednolitego rynku cyfrowego w krajach skandynawskich i bałtyckich, współpraca cyfrowa oraz rozwój spójnej infrastruktury cyfrowej dla obywateli, przedsiębiorstw i administracji całego regionu bałtyckiego. Państwa nordyckie należą wspólnie do najbardziej zdigitalizowanych i innowacyjnych na świecie, ale aby w pełni wykorzystać potencjał tego regionu, rozumieją potrzebę popularyzowania innowacji wśród sąsiadów. Nordycka Rada Ministrów ds. Cyfryzacji proponuje międzynarodowe rozwiązania problemów, które występują wśród obywateli i przedsiębiorstw, a także promuje innowacyjne technologie i pomaga

\footnotetext{
33 Ibidem.

34 The Nordic Council, Policy areas. Get insight into areas where the Nordic countries work together, $<$ https://www.norden.org/en/political_areas>, dostęp 10 IV 2019.
} 
przedsiębiorcom w opracowywaniu nowych usług dla osób fizycznych i przedsiębiorstw w całym regionie. Wszystko to tworzy warunki do rozwoju potencjału regionu ${ }^{35}$.

Drugim projektem zaproponowanym przez Radę Nordycką jest współpraca na rzecz likwidacji barier utrudniających osobom niepełnosprawnym udział w życiu społecznym. Ważnym narzędziem tego projektu jest Rada Współpracy Nordyckiej ds. Niepełnosprawności, której członkowie są wyznaczani przez rządy i organizacje osób niepełnosprawnych z całego regionu. Przyczynia się ona do włączenia tych osób do społeczności poprzez zwiększenie wymiany wiedzy w całym regionie i ścisłą współpracę w kwestiach polityki dotyczącej niepełnosprawności. Obejmuje ona trzy obszary tematyczne: prawa człowieka, zrównoważony rozwój oraz swobodę przemieszczania się. Należy zauważyć, że w regionie nordyckim włączenie osób niepełnosprawnych jest kluczowym wyzwaniem realizacji polityki społecznej. Celem tego projektu jest to, aby każdy obywatel niepełnosprawny miał prawo do uczestnictwa w społeczeństwie na równych warunkach, niezależnie od swoich zdolności fizycznych lub umysłowych. W świetle konstruktywizmu kluczową zasadą jest to, że osoby niepełnosprawne są angażowane w tworzenie polityki, która ich dotyczy. Występuje dialog między organizacjami publicznymi a organizacjami non profit, co w efekcie przynosi wiele korzyści. Wspólnie tworzone są warunki niezbędne do wymiany doświadczeń, zachowania wiedzy specjalistycznej i rozwoju metod integracji osób niepełnosprawnych w wielu strategicznych obszarach, na przykład w zakresie polityki edukacyjnej i badawczej, równości płci i polityki biznesowej. W sektorze kultury dostępność wszystkich instytucji kulturalnych jest niezbędna. Obowiązuje ona producentów kultury, praktyków kultury i publiczność podczas wydarzeń kulturalnych ${ }^{36}$.

Zagwarantowanie różnorodności biologicznej, wyeliminowanie plastiku, który dostaje się do morza, wspólny nordycki wkład w negocjacje klimatyczne i zrównoważone wykorzystanie zasobów naturalnych to jedne z ambitniejszych celów nowego skandynawskiego programu współpracy na rzecz środowiska i klimatu na lata 2019-2024. Jak podkreśliła Karolina Skog, szwedzka minister środowiska: „Dzięki nowemu programowi wzmacniają współpracę nordycką i globalny głos regionu nordyckiego w kwestiach klimatycznych i środowiskowych" ${ }^{37}$. Współpraca w zakresie polityki ochrony środowiska i klimatu doprowadziła do wprowadzenia zaleceń dotyczących zrównoważonego rozwoju w krajach skandynawskich, w UE i na świecie. Udział w negocjacjach międzynarodowych przyczynił się do wdrożenia ambitnego planu monitorowania wdrażania międzynarodowych umów środowiskowych i klimatycznych.

35 The Nordic Council, Nordic co-operation on digitalisation, <https:/www.norden.org/en/informa tion/nordic-co-operation-digitalisation>, dostęp 11 IV 2019.

36 The Nordic Council, Nordic co-operation on disability, <https://www.norden.org/en/informa tion/nordic-co-operation-disability>, dostęp 9 IV 2019; vide Nordiska Ministerrådet, Handlingsplan för nordiskt samarbete om funktionshinder 2018-22, København 2018, < https:/www.norden.org/en/ node/7868Ko>, dostęp 4 IV 2019.

37 Nordisk Råd, Ambisiøst nytt nordisk klima- og miljøsamarbeid, <https://www.norden.org/en/ news/ambisiost-nytt-nordisk-klima-og-miljosamarbeid>, dostęp 11 IV 2019. 
Kolejnym priorytetem Rady Nordyckiej jest kwestia wolności i swobody przemieszczania się. W tym aspekcie projekt Rady Nordyckiej daje możliwość osobom prywatnym oraz firmom swobodę przemieszczania się, studiowania lub prowadzenia działalności gospodarczej w całym regionie nordyckim. Warto zauważyć, że idea otwartego regionu pojawiła się przed podobnymi rozwiązaniami w UE. Sprzyja ona rozwojowi gospodarczemu, ponieważ przepływ siły roboczej pomaga wyrównać nierówności między państwami o wysokim bezrobociu a krajami z niedoborem siły roboczej. Tym samym wspólny rynek pracy pozwolił państwom nordyckim radzić sobie z wahaniami koniunktury i umożliwił im szybszy rozwój gospodarczy. Warto podkreślić, że państwa sąsiadujące stanowią nieproporcjonalnie dużą część rynków importowych i eksportowych każdego nordyckiego państwa. Rada Nordycka sprzyja takiej polityce gospodarczej poprzez różne „imprezy kojarzące”, targi oraz kampanie informacyjne, które są wykorzystywane do stymulowania i ułatwiania działalności transgranicznej ${ }^{38}$.

Innym przejawem egalitaryzmu Rady Nordyckiej jest funkcjonowanie Nordyckiej Rady Młodzieży. Jej obrady są połączone z sesjami jesiennymi Rady Nordyckiej. W skład tego organu wchodzą młodzi działacze polityczni, którzy podejmują wyzwania dotyczące młodzieży i aktualnych problemów współpracy nordyckiej. Wskazane forum polityczne wspiera ideę łatwego dostępu do edukacji i pracy w państwach Europy Północnej w ramach akcji Nordjob i Nordplus. W efekcie jej prac wprowadzono tzw. wspólną studencką kartę nordycką, która umożliwia uzyskanie zniżek w państwach nordyckich. Ponadto podczas sesji Nordycka Rada Młodzieży wysuwa propozycję rozwiązań w takich kwestiach jak ${ }^{39}$ : wzmocnienie nordyckiej solidarności wobec środowiska i klimatu, równość płci, poprawa jakości nauczania języków nordyckich czy też zapobieganie przemocy w Internecie ${ }^{40}$.

Omówione przykłady to tylko wybrane projekty realizowane na wniosek Rady Nordyckiej. Ich cechą charakterystyczną jest włączanie społeczności w realizację celów. Sprzyja to budowaniu struktury głębokiej, a tym samym z utożsamianiem się społeczeństwa państw nordyckich z zasadami i ideami zrównoważonego rozwoju, otwartej gospodarki czy wspieraniem osób niepełnosprawnych.

\section{Struktura powierzchniowa}

Oprócz struktury głębokiej można również wskazać na przykłady funkcjonowania tzw. struktury powierzchniowej w Radzie Nordyckiej. W teorii tworzą ją organizacje międzynarodowe i pozarządowe, rozpowszechniając normy i w ten sposób ucząc inne państwa właściwego zachowania. Rada Nordycka już w umowie z Helsinek zakładała takie działania na arenie międzynarodowej. Obecnie idee zaproponowane przez Radę

${ }^{38}$ The Nordic Council, Freedom of movement, <https://www.norden.org/en/information/freedommovement>, dostęp 10 IV 2019.

${ }^{39}$ Nordic Youht Council, Nordic Regional Youth Camp: Young Eyes on Sustainability in the Arctic Dimension, $<\mathrm{https} / /$ unginorden.org/nyheder?lang=en>, dostęp 9 IV 2019.

${ }^{40}$ Nordic Youht Council, Nordic Young Strategies Against Hate on the Internet, 2017, <https://ungi norden.org/nyheder?lang=en>, dostęp 9 IV 2019. 
Nordycką są nie tylko wdrażane w regionie Europy Północnej, ale również promowane na zewnątrz. Obecnie premierzy chcą podzielić się wiedzą na temat sztandarowych projektów dotyczących takich tematów jak np. Nordic Green, Nordic Gender Effect oraz Nordic Food \& Welfare, korzystając z wiedzy i doświadczenia szerokiego grona ekspertów politycznych, badaczy, podmiotów sektora prywatnego, a także nordyckich ambasad, rad eksportowych i międzynarodowych interesariuszy. Projekty flagowe są odpowiedzią na rosnące globalne zainteresowanie nordyckimi politykami i produktami zrównoważonego rozwoju ${ }^{41}$.

Obecnie jednym $\mathrm{z}$ wielu realizowanych projektów jest promowanie nordyckich rozwiązań w kwestii problemów globalnych (Nordic Solutions to Global Challenges). W październiku 2015 r. premierzy państw członkowskich podjęli decyzję o rozpoczęciu nowej - zaproponowanej przez Radę Nordycką — inicjatywy skoncentrowanej na nordyckich rozwiązaniach globalnych wyzwań społecznych. Należy zauważyć, że państwa nordyckie od dawna starają się stworzyć bardziej zrównoważone społeczeństwa. Celem Rady jest promowanie takich skandynawskich rozwiązań i innowacji, które pomogą w kwestii najbardziej palących problemów globalnych ${ }^{42}$.

Nordic Gender Effect at Work to sztandarowy projekt Rady Nordyckiej, który ma promować równość płci jako cel sam w sobie i jako warunek wzrostu gospodarczego. Na całym świecie rośnie świadomość, że aby osiągnąć zrównoważony wzrost trzeba wykorzystywać potencjał i zdolności całej populacji, zarówno kobiet jak i mężczyzn. Dowodem na to jest globalne zaangażowanie w agendę na rzecz zrównoważonego rozwoju do roku 2030. Ten priorytetowy element jest mocno zakorzeniony w realizacji celów zrównoważonego rozwoju do „niepozostawienia nikogo za sobą”, a konkretnie powiązany z SDG 5 (Sustainable Development Goals) w sprawie równości płci i SDG 8 w sprawie godnych warunków pracy ${ }^{43}$. Państwa nordyckie są przykładem tego, że inwestycje w równość płci przynoszą dobrobyt i korzyści gospodarcze. Choć nadal jest wiele do zrobienia $\mathrm{w}$ regionie $\mathrm{w}$ kwestii likwidacji różnic między płciami, to $\mathrm{w}$ rankingach międzynarodowych państwa nordyckie są światowymi liderami ${ }^{44}$. W czasach, gdy wiele państw ma trudności z postępem w zakresie równości płci, region nordycki w tej kwestii może dzielić się doświadczeniami i wspierać dialog, który może przyspieszyć postępy w skali globalnej i w poszczególnych państwach ${ }^{45}$.

Ciekawym pomysłem jest strategia International Branding of the Nordic Region, która cieszy się szerokim wsparciem zarówno w sektorze publicznym, jak i prywatnym

${ }^{41}$ The Nordic Council, Current initiatives. Keep up with the latest Nordic initiatives and campaigns, $<$ https://www.norden.org/en/current_initiatives>, dostęp 10 IV 2019.

42 The Nordic Council, Nordic Solutions to Global Challenges, <https://www.norden.org/en/infor mation/nordic-solutions-global-challenges>, dostęp 11 IV 2019.

43 The United Nations, Transforming our world: the 2030 Agenda for Sustainable Development, $<$ https://sustainabledevelopment.un.org/post2015/transformingourworld>, dostęp 2 IV 2019.

44 Vide World Economic Forum, The Global Gender Gap Report, <http://www3.weforum.org/docs/ WEF_GGGR_2018.pdf>, dostęp 5 IV 2019.

${ }_{\overline{45}}$ The Nordic Council, About the Nordic Gender Effect at Work, <https://www.norden.org/en/infor mation/about-nordic-gender-effect-work>, dostęp 2 IV 2019. 
oraz w sieciach nordyckich ${ }^{46}$. Powołany do tego sekretariat prowadzi i koordynuje prace nad strategią w dialogu z państwami, które dzielą takie wartości jak otwartość, zaufanie, innowacyjność, zrównoważony rozwój. Ten ambitny projekt pokazuje, że państwa nordyckie są silniejsze razem niż oddzielnie. Wskazuje strategiczne wytyczne dotyczące sposobu promowania na świecie marki regionu i jego interesariuszy. O skuteczności ich działań może świadczyć światowa już marka związana z Nordycką Etykietą Ekologiczną, która jest przyznawana od 1989 r. przez Nordic Council of Ministers. Znak ekologiczny łabędzia posiadają produkty przyjazne dla środowiska zarówno na etapie produkcji, przez użytkowanie i kończąc na utylizacji. Symbol ekologiczny mogą otrzymać wyroby papiernicze, sprzęt AGD, sprzęt elektroniczny, a w zakresie usług baza hotelowa dla turystów. Nie obejmuje on natomiast branży spożywczej i farmaceutycznej ${ }^{47}$.

Kolejny projekt, którym chwalą się Nordycy, to seria wyprodukowanych przez Nordycką Radę Ministrów podcastów. Dzięki niej państwa tego regionu miały możliwość zdobycia wiedzy na temat, w jaki sposób doświadczenia państw nordyckich w radzeniu sobie z takimi problemami jak płeć, odżywianie i zrównoważenie środowiskowe mogą inspirować inne państwa ${ }^{48}$. Czego można nauczyć się od Nordyków i co mogą zyskać inni dzięki ich doświadczeniu w walce z wyzwaniami życia w XXI w.? Taka seria podcastów została nagrana na żywo podczas COP24 - globalnej konferencji na temat zmian klimatu, która odbyła się w grudniu 2018 r. w Polsce. Została zaprezentowana przez byłego korespondenta BBC Richarda Mirona i obejmowała głosy i poglądy czołowych myślicieli, decydentów, działaczy kampanii.

Należy pamiętać, że państwa nordyckie od kilku lat organizują wspólne działania podczas negocjacji klimatycznych COP pod auspicjami Nordyckiej Rady Ministrów — to kolejny projekt Rady Nordyckiej. Podczas szczytów wspólny nordycki pawilon skupia się na rozwiązaniach i wyzwaniach nordyckich oraz na tworzeniu dialogu i dzieleniu się wiedzą na temat sposobów zapewnienia zrównoważonego społeczeństwa dla przyszłych pokoleń. Choć Nordycka Rada Ministrów nie odgrywa formalnej roli w negocjacjach klimatycznych, to poprzez swoje grupy robocze i instytucje wspiera poszukiwania rozwiązań w dziedzinie klimatu i przyczynia się do realizacji agendy klimatycznej. Państwa te mają ambitne plany, aby uwolnić się od paliw kopalnych, a nordyccy ministrowie środowiska zobowiązali się do przywództwa w działaniach na rzecz klimatu. Są wspierani przez skandynawskich premierów, którzy dali zielone światło inicjatywie Nordic Solutions to Global Challenges. Trzeba nadmienić,

${ }^{46}$ Nordic Council of Ministers, Strategy for International Branding of the Nordic Region 2015-2018. The Nordic perspective, Copenhagen 2015, <http://dx.doi.org/10.6027/ANP2015-708>, dostęp 5 III 2019.

47 Vide Nordic Council of Ministers, Goals and Principles for the Nordic Ecolabel (the Swan), 22. October 2014, <https://www.nordic-ecolabel.org/contentassets/89f071a34537452f9e64754c1c049d4a/ goals-and-principles-nordic-ecolabel-oct-2014.pdf>, dostęp 28 II 2019; Nordic Council of Ministers, NordicEcolabelling, Annual report 2016, <https://www.ust.is/library/Skrar/Einstaklingar/Umhverfismerki/ Svanurinn/Annual\%20Report\%202016.pdf>, dostęp 28 III 2019.

48 The Nordic Council, Think Nordic! Podcast: Who are the Nordics to talk about sustainability?, <https://www.norden.org/en/sustainabilitypod>, dostęp 1 IV 2019. 
że państwa nordyckie nie negocjują razem ani nie mają wspólnych stanowisk w kwestiach klimatycznych. Mandat Nordyckiej Grupy Roboczej ds. Globalnych Negocjacji Klimatycznych (NOAK) polega na wspieraniu negocjacji, wdrażaniu porozumienia paryskiego i Ramowej konwencji Narodów Zjednoczonych w sprawie zmian klimatu (United Nations Framework Convention on Climate Change, UNFCCC). Odbywa się to poprzez różne projekty, wydarzenia i warsztaty. Jednym z najgłośniejszych wydarzeń podczas szczytu, który wywarł ogromne wrażenie na młodych ludziach na całym świecie była konferencja prasowa 15-letniej Grety Thunberg — Szwedki, która od września 2018 r. co piątek prowadzi protest przed szwedzkim parlamentem przeciw działaniom prowadzącym do zmiany klimatu. Została zaproszona na szczyt klimatyczny do Katowic, na którym spotkała się między innymi z sekretarzem generalnym ONZ Antonio Guterresem i wzięła udział w Marszu dla Klimatu. Wygłosiła przemówienie, które dotarło do społeczności całego świata przez największe światowe media ${ }^{49}$. Przesłanie tej młodej osoby zmobilizowało młodzież do zainteresowania się problemem globalnego ocieplenia klimatu. Greta Thunberg powiedziała: „Nie szukajmy nadziei, szukajmy działania. Wtedy i tylko wtedy nadzieja przyjdzie. Proszę ludzi z całego świata, żeby zrozumieli, że politycy nas zawiedli. Nie możemy dłużej grać według tych samych reguł. Reguły muszą zostać zmienione. Jeśli kilkoro dzieci może trafić na okładki gazet całego świata, tylko dlatego, że nie poszły do szkoły, to wyobraźcie sobie co moglibyśmy razem osiągnąć. Nasza planeta jest poświęcana, żeby bogaci ludzie w krajach takich, jak mój, mogli żyć w luksusie”. Na apel Grety odpowiedzieli uczniowie szkół w Katowicach i Gliwicach, którzy zamiast do szkoły, przyszli do centrum kongresowego i protestowali. Tym samym zachęciła też młodych Polaków, by dołączali do walki, którą ona prowadzi. Od grudnia 2018 do kampanii chcą dołączyć także uczniowie z całej Polski. Na Facebooku tworzone są wydarzenia, które łączy wspólna data - 15 marca. Analizując oddziaływanie norm, które Szwedka przyjęła za własne, a których — jak wspomina w wywiadzie udzielonym „The New Yorker” - nauczyła się od rodziców oraz w szkole ${ }^{50}$, można dojść do wniosku, że problemy ochrony środowiska są istotne w państwach nordyckich. Co ważne, wiedza i doświadczenie o klimacie są rozpowszechniane już na etapie edukacji szkolnej, co powoduje, że te normy są akceptowane i wdrażane przez społeczeństwo tych państw.

Przykładów na to, jak Nordycy starają się promować własne wartości i zasady na całym świecie, można wymienić dużo więcej. Wśród nich na uwagę zwracają nieomówione wcześniej projekty: Nordic Cultural Initiatives, Food, State of the Nordic

49 J. Sutter, L. Davidson, Teen tells climate negotiators they aren 't mature enough, December 17, 2018, CNN, <https://edition.cnn.com/2018/12/16/world/greta-thunberg-cop24/index.html>, dostęp 4 IV 2019.

50 ,Zawsze mówili mi o tym, że powinniśmy wyłączać światła, oszczędzać wodę i nie wyrzucać jedzenia” - wspominała na łamach tygodnika „The New Yorker” — „Zapytałam dlaczego i wyjaśnili mi, że chodzi o zmiany klimatyczne. Pomyślałam, że to bardzo dziwne. Gdyby ludzie mogli naprawdę zmienić klimat, wszyscy by o tym rozmawiali, ludzie nie mówiliby o niczym innym. Ale tak się nie dzieje". Vide szerzej [mj], COP24: Kim jest Greta Thunberg, nastoletnia aktywistka ekologiczna ze Szwecji?, „Dziennik Zachodni”, 3 XII 2018, <https://dziennikzachodni.pl/cop24-kim-jest-greta-thunberg-nastoletniaaktywistka-ekologiczna-ze-szwecji/ar/13712368>, dostęp 27 III 2019. 
Region, Nordic Food Policy Lab, Generation 2030. Powyżej omówione przykłady pozwalają stwierdzić, że funkcjonowanie Rady Nordyckiej nie ogranicza się do oddziaływania struktury głębokiej, ale mamy do czynienia również ze strukturą powierzchniową. Trzeba również przyznać, że zgodnie z założeniami konstruktywizmu Nordycy wykorzystują nie tylko kanały polityczne, ale do współpracy zapraszają ekspertów, badaczy, jak również zwykłych ludzi, którzy „udomowiają” te projekty, aby stały się jasne, zrozumiałe dla zwykłych obywateli, przez co również stają się im bliższe i łatwiej się można z nimi utożsamiać.

\section{PODSUMOWANIE}

Może dziwić fakt, że państwa nordyckie — położone na peryferiach Europy, w niekorzystnym klimacie, z niewielką liczbą ludności - potrafily odnieść tak duże sukcesy gospodarcze na arenie światowej ${ }^{51}$. Jednak uwzględniając założenia konstruktywizmu, można wskazać, że znalazły właściwą drogę, aby osiągnąć własne strategiczne cele. Wykorzystały dwa czynniki, które powiązane ze sobą przyczyniły się do tego, że państwa nordyckie nie tylko są przykładem wdrażania norm i zasad globalnych, ale sami są inicjatorami takich właśnie działań. Pierwszy z tych czynników dotyczy stosowania się do przyjętych i uzgodnionych norm. Każde z państw nordyckich wdrażało przyjęte przez Radę Nordycką normy i zasady w takich aspektach jak: rozwój gospodarczy, ochrona środowiska zrównoważony rozwój etc. Ponadto wskazane w artykule przykłady kształtowania się struktury głębokiej w społeczeństwie państw nordyckich pokazują, że jednostki (np. sławna na całym świcie Szwedka Greta Thunberg) lub grupy (organizacje pozarządowe, organizacje non profit), są zaangażowane we wdrażanie proponowanych przez Radę Nordycką projektów.

Drugi czynnik to efekt synergii, jaki powstał w wyniku współpracy tych państw. Warto podkreślić rolę i znaczenie współpracy tych podmiotów stosunków międzynarodowych oraz chęć niesienia pomocy nie tylko w ramach grupy nordyckiej, ale również wobec państw słabiej rozwiniętych (realizacja projektów w szerszym gronie państw, włączenie państw bałtyckich do realizacji celów związanych np. z energią, czystym Bałtykiem).

Jak pokazuje geneza Rady Nordyckiej, państwa te połączyły wspólne korzenie, wspólna tradycja oraz wspólne wartości. W historii rozwoju tej organizacji trudno doszukać się sytuacji kryzysowych, natomiast można znaleźć przykłady, kiedy od własnych interesów ważniejsze były wspólne idee i wartości. W efekcie Radę Nordycką można traktować jako szczególny przypadek funkcjonowania prawa międzynarodowego, gdzie kantowskie przekonanie o kulturze przyjaźni wzięło górę nad typową dla tego okresu w historii kulturą rywalizacji i konfliktu.

Unikalny charakter nordyckiej kultury wynika z wielu czynników. Przede wszystkim doświadczenia państw nordyckich mają długoletnią tradycję, która jest głęboko

${ }^{51}$ C.S. Browning, Small, Smart and Salient? Rethinking Identity in the Small States Literature, „Cambridge Review of International Affairs” 2006, nr 4, s. 669-684. 
zakorzeniona w myśleniu obywateli. Państwa nordyckie od czasu powstania Rady Nordyckiej nie odeszły od wskazanych w latach pięćdziesiątych XX w. moralnych wartości, jak współpraca, pomoc, rozwój. Normy te nadal stanowią największą wartość, określającą ramy i zasady działania tej organizacji. Nie da się ustanowić prawa i nakazać państwom współpracować ze sobą, dzieląc wspólne wartości. Rada Nordycka jest organizacją unikalną, ponieważ nie tylko ustanawia prawa i obowiązki, ale też je realizuje. Oznacza to, że Nordycy nie narzucają norm, aby inni byli równi, ale dbają przede wszystkim o to, aby sami byli równi, nie nakazują stosować zasad zrównoważonej ekonomii, ale sami angażują się na rzecz zrównoważonego rozwoju, nie mówią o solidarności z grupami wykluczonymi, ale sami likwidują bariery uniemożliwiające niepełnosprawnym aktywne życie.

Podsumowując, państwa nordyckie skutecznie realizują cele wyznaczane przez przedstawicieli parlamentów tych państw. Przeważa podejście typowe dla zarządzania, które jest nastawione na realizację konkretnych celów, wdrażanie konkretnych zasad i idei, a nie uprawianie polityki. Co ciekawe, państwa nastawione nie na rywalizację i konflikt — bycie lepszym, silniejszym w stosunkach międzynarodowych — osiągają lepsze na świecie wyniki w rankingach konkurencyjności, innowacyjności czy zrównoważonego rozwoju ${ }^{52}$. Zyskuje też na tym społeczeństwo państw nordyckich, które $\mathrm{w}$ rankingu najszczęśliwszych państw świata $(\mathrm{WHI})^{53}$ zajmują miejsca w pierwszej dziesiątce.

\section{BIBLIOGRAFIA}

\section{ŹRÓDŁA}

Nordic Council of Ministers, Goals and Principles for the Nordic Ecolabel (the Swan), 22. October 2014, <https://www.nordicecolabel.org/contentassets/89f071a34537452f9e64754c1c049 d4a/goals-and-principles-nordic-ecolabel-oct-2014.pdf $>$.

Nordic Council of Ministers, Nordic Ecolabelling, Annual report 2016, <https:/www.ust.is/ library/Skrar/Einstaklingar/Umhverfismerki/Svanurinn/Annual\%20Report\%202016.pdf>.

Nordic Council of Ministers, Strategy for International Branding of the Nordic Region 2015-2018. The Nordic perspective, Copenhagen 2015, <http://dx.doi.org/10.6027/ANP20 15-708>.

Nordiska Ministerrådet, Handlingsplan för nordiskt samarbete om funktionshinder 2018-22, København 2018, <https://www.norden.org/en/node/7868Ko>.

Swedish Institute, The Nordic Way. Equality, Individuality and Social Trust, Stockholm 2012, $<$ https://www.globalutmaning.se/wp-content/uploads/sites/8/2011/01/Davos-The-nordicway-final.pdf $>$.

The Nordic Council, About the Nordic Gender Effect at Work, <https://www.norden.org/en/ information/about-nordic-gender-effect-work>.

52 Swedish Institute, The Nordic Way. Equality, Individuality and Social Trust, Stockholm 2012, $<$ https://www.globalutmaning.se/wp-content/uploads/sites/8/2011/01/Davos-The-nordic-way-final.pdf $>$, dostęp 9 IV 2019.

53 The United Nation, World Happiness Report, < https://countryeconomy.com/demography/worldhappiness-index>, dostęp 10 IV 2019. 
The Nordic Council, Forretningsorden for Nordisk Råd, <https://www.norden.org/en/informa tion/forretningsorden-nordisk-rad>.

The Nordic Council, Freedom of movement, <https://www.norden.org/en/information/free dom-movement>.

The Nordic Council, Nordic co-operation on digitalisation, <https://www.norden.org/en/infor mation/nordic-co-operation-digitalisation>.

The Nordic Council, Nordic co-operation on disability, <https://www.norden.org/en/informa tion/nordic-co-operation-disability>.

The Nordic Council, Policy areas. Get insight into areas where the Nordic countries work together, <https://www.norden.org/en/political_areas>.

The Nordic Council, Think Nordic! Podcast: Who are the Nordics to talk about sustainability? $<$ https://www.norden.org/en/sustainabilitypod $>$.

The Nordic Youht Council, Nordic Regional Youth Camp: Young Eyes on Sustainability in the Arctic Dimension, <https://unginorden.org/nyheder?lang=en>.

The Nordic Youht Council, Nordic Young Strategies Against Hate on the Internet, 2017, $<$ https://unginorden.org/nyheder?lang=en $>$.

The United Nations, Transforming our world: the 2030 Agenda for Sustainable Development, $<$ https://sustainabledevelopment.un.org/post2015/transformingourworld $>$.

World Economic Forum, The Global Gender Gap Report, <http://www3.weforum.org/docs/ WEF_GGGR_2018.pdf $>$.

\section{PIŚMIENNICTWO}

Albert M., Observing World Politics. Luhmann's Systems Theory of Society and International Relations, „Millenium” 1999, t. 28, nr 2, https://doi.org/10.1177/03058298990280020701.

Ashley R.K., The Poverty of Neo-realism, „International Organization” 1984, nr 3.

Browning C.S., Small, Smart and Salient? Rethinking Identity in the Small States Literature, „Cambridge Review of International Affairs” 2006, nr 4, https://doi.org/10.1080/ 09557570601003536.

COP24: Kim jest Greta Thunberg, nastoletnia aktywistka ekologiczna ze Szwecji?, „Dziennik Zachodni”, 3 XII 2018, <https://dziennikzachodni.pl/cop24-kim-jest-greta-thunberg-nasto letnia-aktywistka-ekologiczna-ze-szwecji/ar/13712368>.

Czaputowicz J., Teorie stosunków międzynarodowych. Krytyka i systematyzacja, Wydawnictwo Naukowe PWN, Warszawa 2008.

Doliwa-Klepacki Z., Ławniczak R., Rada Nordycka a wspótpraca i integracja państw skandynawskich, Warszawa 1978.

Dośpiał-Borysiak K., Northern Europe. New Political, Economic and Social Trends, „International Studies. Interdisciplinary Political and Cultural Juornal” 2017, t. 20, nr 1, https://doi. org/10.1515/ipcj-2017-0013.

Filipek M.J., Struktura organizacyjna oraz główne kierunki działalności Nordyckiej Rady Ministrów, „Zeszyty Prawnicze UKSW” 2009, nr 2, http://dx.doi.org/10.21697/zp.2009.9.2.05.

Grzela J., Płaszczyzny i kierunki współpracy nordyckiej, Uniwersytet Jana Kochanowskiego w Kielcach, Kielce 2014.

Guzzini S., A Reconstruction of Constructivism in International Relations, „European Journal of International Relations" 2000, t. 6, nr 2, https://doi.org/10.1177/1354066100006002001.

Habermas J., Teoria działania komunikacyjnego, Wydawnictwo Naukowe PWN, tłum. Andrzej Maciej Kaniowski, t. 1, Warszawa 1999, t. 2, Warszawa 2002.

Hedtoft H., Nordisk Råd, „Nordisk Administrativt Tidskrift” 1953.

Herlitz N., Nordiska rådets tillkmst. Minnen från 1951-1953, Stockholm 1962. 
Hilson M., The Nordic Model: Scandinavia since 1945, Reaktion, London 2008.

Hopf T., The Promise of Constructivism in International Relations Theory, „International Security" 1998, t. 23, nr 1, https://doi.org/10.1162/isec.23.1.171.

Institutional Structure. Constituting State, Society, and Individual, red. G.M. Thomas, J. Meyer, F.O. Ramirez, J. Boli, Sage, Newbury Park, Ca 1987.

Karich H.D., Der Nordische Rat. Institution skandinavischer Gemeinsamkeit im Umfeld divergierender sicherheits- und wirtschaftlicher Interessen der Mitgliedstaaten, Diss, Kiel 1999.

Luhmann N., Essays on Self-Reference, Columbia University Press, New York 1990.

Meyer J., Boli W.J., Thomas G.M., Ramirez F.O., World Society and the Nation State, „American Journal of Sociology" 1997, t. 103, nr 1.

Musiał K., Roots of the Scandinavian Model. Images of Progress in the Era of Modernisation, Nomos Verlagesellschaft, Berlin 2000.

Nowiak J., Wspótpraca nordycka. Wzór dobrej polityki, Wydawnictwo Naukowe Wyższej Szkoły Nauk Humanistycznych i Dziennikarstwa, Poznań 2001.

Onuf N., A Constrctivism Manifesto, [w:] Constituting International Political Economy, red. K. Burch, R.A. Denemark, Lynne Rienner Publishers, London 1997.

Petren G., The Nordic Council. A Unique Factor in International Law, „Nordisk Tidskrift for International Ret og Jus Gentium" 1959, t. 29, nr 4, https://doi.org/10.1163/157181059 X00193.

Piotrowski B., Integracja Skandynawii. Od Rady Nordyckiej do wspólnoty europejskiej, Wydawnictwo Naukowe Uniwersytetu im. Adama Mickiewicza w Poznaniu, Poznań 2005.

Rees W., The Theory of Sovereignty Restated, „Mind” 1950, t. 59, nr 236.

Rhetorics of Nordic Democracy, red. J. Kurunmäki, J. Strang, Finnish Literature Society, Helsinki 2010, https://doi.org/10.21435/sfh.17.

Ruggie J.G., Continuity and Transformation in the World Polity. Towards a Neorealist Synthesis, „World Politics” 1983, t. 2, nr 35, t. 2, https://doi.org/10.2307/2010273.

Strang J., Introduction: The Nordic Model of Transnational Cooperation, [w:] Nordic Cooperation: A European Region in Transition, red. J. Strang, Routledge, London 2016.

Sutter J., Davidson L., Teen tells climate negotiators they aren't mature enough, December 17, 2018, CNN, <https://edition.cnn.com/2018/12/16/world/greta-thunberg-cop24/index.html>.

The Cold War and the Nordic Countries: Historiographies at the Crossroads, red. T.B. Olesen, University Press of Southern Denmark, Odense 2004.

Wendt A., Social Theory of International Politics, Cambridge University Press, Cambridge 1999, https://doi.org/10.1017/cbo9780511612183.

Wendt A., The Agent Structure Problem in International Relations Theory, „International Organization" 1987, t. 41, nr 3, https://doi.org/10.1017/s002081830002751x.

Wendt F., Cooperation in the Nordic Countries. Achievements and Obstacles, Almqvist \& Wiksell Intl, Stockholm 1981.

Wiklund C., 1962 års Helsingavtal, [w:] Norden i sicksack. Tre spårbyten inom nordiskt samarbete, red. B. Sundelius C. Wiklund, Santérus förlag, Stockholm 2000.

Zięba R., Rola ugrupowań subregionalnych w nowym systemie bezpieczeństwa europejskiego, „Studia Europejskie” 2000, nr 1.

Zygierewicz A., Wspótpraca państw nordyckich, Kancelaria Sejmu, Biuro Studiów i Ekspertyz, styczeń 2005, nr 1115. 